\title{
A new Oligocene site with terrestrial mammals and a selachian fauna from Minqar Tibaghbagh, the Western Desert of Egypt
}

\author{
Hendrik Jan Van Vliet, Anne S. Schulp, Gebely A.M.M. Abu El-Kheir, Theo M. Paijmans, Mark \\ Bosselaers, and Charles J. Underwood \\ Acta Palaeontologica Polonica 62 (3), 2017: 509-525 doi:https://doi.org/10.4202/app.00341.2017
}

A new fossil site at Minqar Tibaghbagh, east of Siwa, in the Egyptian Western Desert is described. This represents the first place in Egypt outside the Fayum Depression yielding Paleogene, terrestrial mammals. Initial studies indicate the presence of palaeomastodonts, hyracoids, and anthracotheres, presumably early Oligocene in age. As only surface prospecting has been performed, more taxa will almost certainly be discovered in future investigations here and probably also elsewhere in the surroundings. A comparison is made with the most important contemporaneous sites in Libya and Egypt that yield terrestrial mammal remains. The selachian fauna from a higher level in the section confirms the Paleogene age of the subjacent strata. It is compared with selachians faunas from the early Oligocene Eastern Tethys Ocean at other places (the Fayum Depression in Egypt, and sites in Oman and Pakistan), and differs from these sites in being fully marine. Contrary to earlier studies, the open marine mudstones of the Daba'a Formation at Minqar Tibaghbagh are overlain by Paleogene marine sediments of most probably early Oligocene age and not early Miocene marine sediments as previously reported. These strata represent not only a new site with great potential for future finds, but also allows for biostratigraphic correlation.

Key words: Mammalia, Palaeomastodontidae, Hyracoidea, Anthracotheriidae, Chondrichthyes, Oligocene, Egypt.

Henk Jan van Vliet [henkjanvanvliet@yahoo.com] and Theo M. Paijmans [tpaymans@yahoo.com ], Abel Tasmanstraat 41, 3531 GS Utrecht, The Netherlands. Anne S. Schulp [anne.schulp@naturalis.nl ], Naturalis Biodiversity Center, Darwinweg 2, 2333 CR Leiden, The Netherlands, and Faculty of Earth and Life Sciences, the Vrije Universiteit Amsterdam, De Boelelaan 1105, 1081 HV Amsterdam, The Netherlands. Gebely A.M.M. Abu El-Kheir [gebely2006@scinv.au.edu.eg], Assiut University, Assiut 71591, Egypt. Mark E.J. Bosselaers [mark.bosselaers@ telenet.be

], Koninklijk Belgisch Instituut voor Natuurwetenschappen, Vautierstraat 29, 1000 Brussel, Belgium; and Koninklijk Zeeuwsch Genootschap der Wetenschappen, Koudsteensedijk 7, 4331 JE Middelburg, The Netherlands. Charles J, Underwood [c.underwood@bbk.ac.uk], Department of Earth and Planetary Science, Birkbeck College, Malet Street, London WC1E 7HX, UK. 
This is an open-access article distributed under the terms of the Creative Commons Attribution License (for details please see creativecommons.org), which permits unrestricted use, distribution, and reproduction in any medium, provided the original author and source are credited.

FaF 